\title{
Bernard-Soulier syndrome (Hemorrhagiparous thrombocytic dystrophy) François Lanza*1,2
} Address: ${ }^{1}$ EFS-Alsace, Strasbourg, France; Inserm, U311, Strasbourg, France; Université Louis Pasteur, Strasbourg, France and 2INSERM U311/EFS-
Alsace, 10 rue Spielmann F, 67065 Strasbourg, France

Email: François Lanza* - francois.lanza@efs-alsace.fr

* Corresponding author

Published: 16 November 2006

Orphanet Journal of Rare Diseases 2006, I:46 doi:I0.I I86/I750-II72-I-46

This article is available from: http://www.OJRD.com/content/I/I/46

(C) 2006 Lanza; licensee BioMed Central Ltd.

This is an Open Access article distributed under the terms of the Creative Commons Attribution License (http://creativecommons.org/licenses/by/2.0), which permits unrestricted use, distribution, and reproduction in any medium, provided the original work is properly cited.

\begin{abstract}
Bernard-Soulier syndrome (BSS), also known as Hemorrhagiparous thrombocytic dystrophy, is a hereditary bleeding disorder affecting the megakaryocyte/platelet lineage and characterized by bleeding tendency, giant blood platelets and low platelet counts. This syndrome is extremely rare as only $\sim 100$ cases have been reported in the literature. Clinical manifestations usually include purpura, epistaxis, menorrhagia, gingival and gastrointestinal bleeding. The syndrome is transmitted as an autosomal recessive trait. The underlying defect is a deficiency or dysfunction of the glycoprotein GPIb-V-IX complex, a platelet-restricted multisubunit receptor required for normal primary hemostasis. The GPIb-V-IX complex binds von Willebrand factor, allowing platelet adhesion and platelet plug formation at sites of vascular injury. Genes coding for the four subunits of the receptor, GPIBA, GPIBB, GP5 and GP9, map to chromosomes $17 \mathrm{p} / 2$, 22q I I.2, 3q29, and 3q2I, respectively. Defects have been identified in GPIBA, GPIBB, and GP9 but not in GP5. Diagnosis is based on a prolonged skin bleeding time, the presence of a small number of very large platelets (macrothrombocytopenia), defective ristocetin-induced platelet agglutination and low or absent expression of the GPIb-V-IX complex. Prothrombin consumption is markedly reduced. The prognosis is usually good with adequate supportive care but severe bleeding episodes can occur with menses, trauma and surgical procedures. Treatment of bleeding or prophylaxis during surgical procedures usually requires platelet transfusion.
\end{abstract}

\section{Disease name and synonyms \\ Bernard-Soulier syndrome (BSS)}

Hemorrhagiparous thrombocytic dystrophy

Congenital hemorrhagiparous thrombocytic dystrophy

\section{Definition and diagnostic criteria}

The Bernard-Soulier syndrome (BSS) is an autosomal recessive disease associated with bleeding tendency, giant blood platelets and low platelet counts. The defect is restricted to the megakaryocyte/platelet lineage.

Congenital platelet disorders are often difficult to distinguish on the basis of clinical manifestations and require specialized laboratory tests. Functional analysis of platelet suspensions by aggregometry is needed to differentiate BSS from other rare inherited disorders accompanied by macrothrombocytopenia, such as the May-Hegglin, Sebastian, Fechtner and Epstein's syndromes [1]. A firm diagnosis calls for conjunction of increased bleeding 
times, macrothrombocytopenia, defective ristocetininduced agglutination and low or absent levels of platelet GPIb-V-IX (CD42a-d) by flow cytometry.

\section{Epidemiology}

This syndrome is extremely rare as only 100 cases have been reported in published articles, mostly in the populations of Japan, Europe, and North America. Prevalence has been estimated at less than $1 / 1,000,000$ but is probably higher due to misdiagnosis and underreporting. This low frequency could probably be explained by the fact that the affected genes are very compact being interrupted by only 1 or 2 introns.

\section{Clinical description}

In 1948, Jean Bernard and Jean-Pierre Soulier [2], two French hematologists, described a young male patient who had a severe bleeding defect with a prolonged bleeding time, a low platelet count with very large platelets (macrothrombocytopenia). In view of these defects, they named the disorder "Dystrophie thrombocytaire-hémorragipare congénitale" (Hemorrhagiparous thrombocytic dystrophy). Additional cases presenting with an identical disorder, mostly transmitted as an autosomal recessive trait and often associated with consanguinity, have been subsequently reported $[3,4]$. In the literature, the disease is now commonly referred to as Bernard-Soulier syndrome (BSS). In most cases, bleeding symptoms manifest rapidly after birth or during early childhood. Clinical manifestations usually include purpura, epistaxis, gingival bleeding and menorrhagia, and more rarely gastrointestinal bleeding and hematuria. Severe bleeding episodes are associated with trauma and surgical procedures such as tonsillectomy, appendectomy, splenectomy, or occur during dental extractions and menses. However, the severity and frequency of bleeding vary between individuals. Bleeding mainly affects mucocutaneous tissues, and major hematomas are very rarely observed.

\section{Etiology}

Defects in three genes give rise to the typical clinical features and platelet anomalies associated with BSS. This is due to the multisubunit nature of the affected GPIb-V-IX receptor, whose structure is shown in Figure 1. The main function of the GPIb-V-IX complex is to ensure normal primary hemostasis by initiating platelet adhesion at sites of vascular injury [5]. Adhesion is brought by its binding to von Willebrand factor, itself captured from plasma by subendothelial collagen [6]. Four distinct transmembrane proteins, GPIb $\alpha$ (MW $135 \mathrm{kDa}$ ), GPIb $\beta$ (MW $26 \mathrm{kDa}$ ), GPIX (MW $20 \mathrm{kDa}$ ) and GPV (MW $82 \mathrm{kDa}$ ) assemble to form the functional receptor at the surface of bone marrow megakaryocytes, the precursors of mature circulating platelets [7]. GPIb $\alpha$, GPIb $\beta$, and GPIX are closely associated and are all required for efficient biosynthesis of the receptor [8]. A lack of a single subunit dramatically decreases surface expression of the whole complex. GPV is more loosely associated and its absence does neither prevent expression, nor von Willebrand factor binding function. The four subunits are separately encoded by genes mapping to chromosomes 17p12 (GPIBA), 22q11.2 (GPIBB), 3q29(GP5) and 3q21 (GP9) [9-15]. The four genes belong to the leucine-rich family of proteins and are exclusively expressed in platelets under physiological conditions. They have a simple structure with the coding sequence contained within a single exon, except for GPIBB which contains an intron of 10 bases after the start codon.

To date, 47 different genetic defects associated to the BSS have been identified [see Additional file 1]. A BernardSoulier registry can also be found at Bernard-Soulier syndrome web site [16]. Defects are due to mutations in GPIBA (20 mutations), which is the largest subunit and bears the von Willebrand binding site, in GPIBB (16 mutations) and in GP9 (11 mutations). The defects can be separated into three major classes: 1) missense mutations or short in-frame deletions which rarely give rise to normal or slightly decreased expression of a dysfunctional receptor or more often to an abnormal/unstable complex with strongly decreased surface expression; 2) nonsense mutations resulting in smaller subunits that typically lack the transmembrane domain; 3) frameshift insertions or deletions leading to a novel polypeptide sequence and often to a premature stop. In very few cases, a single mutation, like in some GPIb $\alpha$ and GPIX mutants, affects mainly the function of the receptor, which is at least partially expressed in giant platelets. Most of the defects are unique to a single individual or family. One exception is the GP9 Asn45Ser mutation, which has been reported in

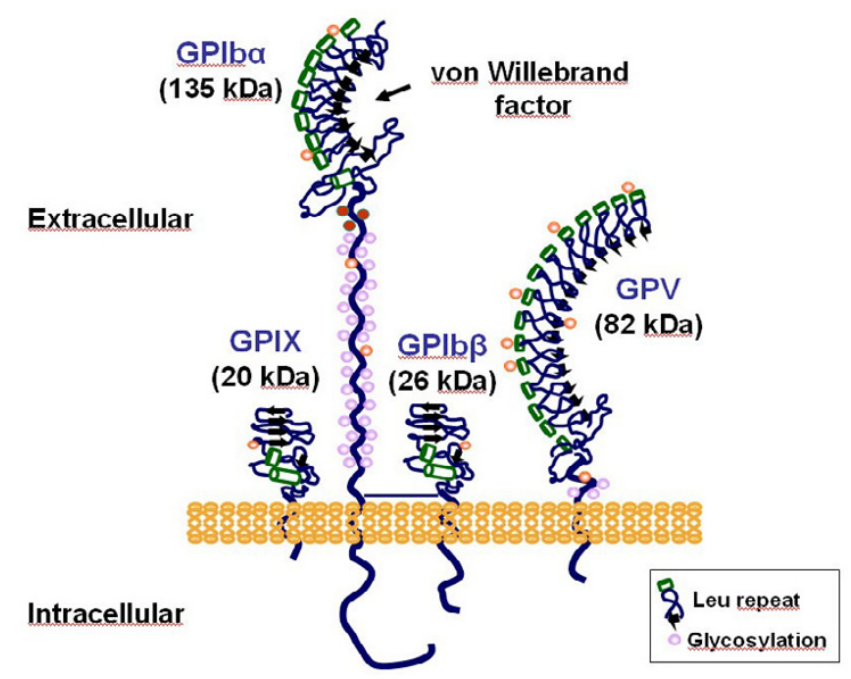

Figure I

The platelet GPIb-V-IX complex. 
several families from different countries, probably as a result of a founder effect [17]. The Ala156Val mutation also occurs frequently in the Italian population, with an apparent dominant transmission leading to macrothrombocytopenia in heterozygote individuals [18]. Several mutations combining a BSS phenotype and the DiGeorge/ Velo-cardio-facial syndrome (VCF) have been reported. In these cases, one allele carried a mutated GPIBB gene, while the other allele had the large deletion of the chromosomal region 22q11.2, containing the GPIBB gene, typical of the Di George/VCF defect [19].

Several polymorphisms have been reported especially in the GPIBA gene. They include silent mutations, a missense mutation which gives rise to an alloantigen and a variable number of tandem repeat (VNTR) polymorphism [20]. To date, none of these polymorphisms have been linked to anomalies in receptor expression or function.

Rare gain of function mutations of GPIBA give rise to platelet-type von Willebrand disease, a clinical entity distinct from BSS. The condition resembles type IIB von Willebrand disease due to clearance of plasma von Willebrand factor by aggregated platelets. Three missense mutations in a disulfide loop flanking the leucine-rich domain and a 9 amino acid deletion in the macroglycopeptide have been reported in these patients [21-24].

\section{Diagnostic methods}

Skin bleeding times in BSS are moderately (5-10 min) to severely $(>20 \mathrm{~min})$ prolonged. A constant feature is the presence of a small number of very large platelets with a rounded shape (main volume 11-16 $\mu^{3}$; diameter 4-10 $\mu \mathrm{m})$. The initial laboratory test should therefore include blood cell counts and examination of blood smears. Platelet counts typically range from 20,000 to $100,000 / \mu$ l. Manual counting is required for an accurate determination as the very large platelets in BSS are often mistaken for lymphocytes in automatic counters. The distinctive abnormality of BSS platelets is an isolated defect in ristocetin-induced agglutination. Unlike the defect in von Willebrand disease, this anomaly is not corrected by the addition of normal plasma. Levels of FVIII-von Willebrand complex are assessed. Aggregation responses to agonists such as ADP or collagen are normal, however decreased responses to thrombin can be observed. A marked defect in prothrombin consumption is constantly observed and may be useful for the diagnosis: it is attributed to a defective binding of FXI due to a lack of GPIb [25], and to a decrease in GPIb-fibrin-dependent thrombin generation $[26,27]$. Flow cytometry analysis using a panel of specific monoclonal antibodies (CD42 ad) will confirm this diagnosis. Additional tests in specialized research units may include platelet glycoprotein analysis by SDS-polyacrylamide gel separation and immunoblotting, and finally, study of genetic abnormalities.

\section{Differential diagnosis}

BSS belongs to a heterogeneous group of rare inherited diseases characterized by a reduced number of platelets (thrombocytopenia). A published diagnostic algorithm should facilitate differential diagnosis of BSS [28]. For example, presence of small platelets is typical of WiscottAldrich syndrome and X-linked thrombocytopenia. Giant platelets associated with neutrophil inclusions will orient toward MYH9-related diseases (May-Hegglin, Sebastian, Fechtner, and Epstein syndromes). Other parameters will help diagnose macrothrombocytopenia in Di George, Gray platelet, Montreal and Paris-Trousseau syndromes. Finally, some cases of heterozygous BSS can also exhibit macrothrombocytopenia.

BSS is difficult to be distinguished on the basis of clinical manifestations only and has often been misdiagnosed as idiopathic thrombocytopenic purpura (ITP), an immunological disorder, and treated unsuccessfully with steroids or splenectomy.

\section{Genetic counseling}

Genetic counseling should follow the standards established for all autosomal recessive diseases.

\section{Antenatal diagnosis}

Prenatal diagnosis is theoretically feasible when the genetic defect has been identified in a particular kindred. This is probably not justified as the syndrome rarely gives rise to life threatening bleeding. With a good prophylaxis, a fairly normal quality of life can be maintained. In addition, cord blood or chorion villus sampling bear a high risk of bleeding and premature abortion.

\section{Management}

Therapeutic approaches include both general and specific treatment of bleeding. Patients should be warned to avoid traumas, antiplatelet medication such as aspirin, to maintain adequate dental hygiene and to use contraceptive in female at puberty. Treatment of bleeding or prophylaxis during surgical procedures usually requires blood or platelet transfusion with the associated risk of developing antiplatelet alloantibodies. Desmopressin and rFVIIa administration have been shown to shorten the bleeding time in some patients. In rare cases of patients with lifethreatening disorders, bone-marrow or umbilical-cord hematopoietic stem cell transplantation may be considered [29]. As a rather simple genetic defect, BSS could be a candidate for future gene replacement therapy using virally transduced megakaryocyte progenitors. 


\section{Prognosis}

With a good education, adequate care and prevention of trauma, patients can live a fairly normal life. Nevertheless, possible occurrence of severe bleeding in case of trauma and surgical intervention should always be kept in mind and treated adequately.

\section{Unresolved questions}

To date, no BSS patient has been identified with a mutation of the GPV subunit but existence of such defects cannot be ruled out, and they could potentially result in variant or mild forms of BSS.

As for other platelet deficiencies, it is difficult to correlate genetic defects with propensity to bleed and severity of bleeding.

The molecular and cellular mechanisms responsible for the several platelet defects encountered in BSS are still largely unknown. An explanation for their enlarged platelets and low platelet counts is probably related to defective megakaryocytopoiesis but such studies are difficult to conduct in BSS patients. Additionally, platelet functional studies in vivo and evaluation of a putative protection against thrombosis are not amenable in BSS patients. Finally, there is no clear explanation for the abnormal prothrombin consumption in this pathology. Mouse models of BSS are now available with deletions of the GPIb $\alpha$ or GPIb $\beta$ subunit which should help answering these remaining questions.

\section{Additional material}

\section{Additional file 1}

Genetic defects in Bernard-Soulier syndrome. This is a table that represents the genetic defects in Bernard-Soulier syndrome and corresponding references.

Click here for file

[http://www.biomedcentral.com/content/supplementary/17501172-1-46-S1.doc]

\section{References}

I. Nurden AT: Qualitative disorders of platelets and megakaryocytes. J Thromb Haemost 2005, 3: $1773-1782$.

2. Bernard J, Soulier JP: Sur une nouvelle variété de dystrophie thrombocytaire-hémorragipare congénitale. Sem Hop Paris 1948, 24:3217-3222.

3. de la Salle C, Lanza F, Cazenave JP: Biochemical and molecular basis of Bernard-Soulier syndrome: a review. Nouv Rev Fr Hematol 1995, 37:215-222.

4. Lopez JA, Andrews RK, Afshar-Kharghan V, Berndt MC: BernardSoulier syndrome. Blood 1998, $91: 4397-4418$.

5. Clemetson $\mathrm{KJ}$ : Platelet receptors and their role in diseases. Clin Chem Lab Med 2003, 41:253-260.

6. Ruggeri ZM: Von Willebrand factor, platelets and endothelial cell interactions. J Thromb Haemost 2003, I: I335-1343.
7. Andrews RK, Shen Y, Gardiner EE, Dong JF, Lopez JA, Berndt MC: The glycoprotein Ib-IX-V complex in platelet adhesion and signaling. Thromb Haemost 1999, 82:357-364.

8. Ulsemer P, Strassel C, Baas MJ, Salamero J, Chasserot-Golaz S, Cazenave JP, de la Salle C, Lanza F: Biosynthesis and intracellular post-translational processing of normal and mutant platelet glycoprotein GPIb-IX. Biochem / 200I, 358:295-303.

9. Lopez JA, Chung DW, Fujikawa K, Hagen FS, Papayannopoulou T, Roth G]: Cloning of the alpha chain of human platelet glycoprotein Ib: a transmembrane protein with homology to leucine-rich alpha 2-glycoprotein. Proc Natl Acad Sci USA 1987, 84:5615-5619.

10. Wenger RH, Wicki AN, Kieffer N, Adolph S, Hameister H, Clemetson $\mathrm{KJ}$ : The $\mathbf{5}^{\prime}$ flanking region and chromosomal localization of the gene encoding human platelet membrane glycoprotein Ib alpha. Gene 1989, 85:5 17-524.

II. Lopez JA, Chung DW, Fujikawa K, Hagen FS, Davie EW, Roth G): The alpha and beta chains of human platelet glycoprotein Ib are both transmembrane proteins containing a leucine-rich amino acid sequence. Proc Natl Acad Sci USA 1988, 85:2 I 35-2 39.

12. Yagi M, Edelhoff S, Disteche CM, Roth G]: Structural characterization and chromosomal location of the gene encoding human platelet glycoprotein Ib beta. J Biol Chem 1994, 269: 17424-17427.

13. Lanza F, Morales M, de la Salle C, Cazenave JP, Clemetson KJ, Shimomura T, Phillips DR: Cloning and characterization of the gene encoding the human platelet glycoprotein V. A member of the leucine-rich glycoprotein family cleaved during thrombin-induced platelet activation. I Biol Chem 1993, 268:2080I-20807.

14. Hickey MJ, Deaven LL, Roth G]: Human platelet glycoprotein IX. Characterization of CDNA and localization of the gene to chromosome 3. FEBS Lett 1990, 274:189-192.

15. Yagi M, Edelhoff S, Disteche CM, Roth GJ: Human platelet glycoproteins $V$ and IX: mapping of two leucine-rich glycoprotein genes to chromosome 3 and analysis of structures. Biochemistry 1995, 34:16132-16137.

16. Bernard-Soulier Syndrome [http://www.bernardsoulier.org]

17. Liang HP, Morel-Kopp MC, Clemetson JM, Clemetson KJ, Kekomaki R, Kroll H, Michaelides K, Tuddenham EG, Vanhoorelbeke K, Ward CM: A common ancestral glycoprotein (GP) 9 I828A>G (Asn45Ser) gene mutation occurring in European families from Australia and Northern Europe with Bernard-Soulier Syndrome (BSS). Thromb Haemost 2005, 94:599-605.

18. Savoia A, Balduini CL, Savino M, Noris P, Del Vecchio M, Perrotta $S$, Belletti S, Poggi, lolascon A: Autosomal dominant macrothrombocytopenia in Italy is most frequently a type of heterozygous Bernard-Soulier syndrome. Blood 200I, 97:। 330-I 305.

19. Budarf ML, Konkle BA, Ludlow LB, Michaud D, Li M, Yamashiro DJ, McDonald-McGinn D, Zackai EH, Driscoll DA: Identification of a patient with Bernard-Soulier syndrome and a deletion in the DiGeorge/velo-cardio-facial chromosomal region in $22 q 1$ I.2. Hum Mol Genet 1995, 4:763-766.

20. Lopez JA, Ludwig EH, McCarthy BJ: Polymorphism of human glycoprotein Ib alpha results from a variable number of tandem repeats of a 13-amino acid sequence in the mucin-like macroglycopeptide region. Structure/function implications. J Biol Chem 1992, 267: 10055-10061.

21. Miller JL, Cunningham D, Lyle VA, Finch CN: Mutation in the gene encoding the alpha chain of platelet glycoprotein Ib in platelet-type von Willebrand disease. Proc Natl Acad Sci USA 199I, 88:476I-4765.

22. Russell SD, Roth GJ: Pseudo-von Willebrand disease: a mutation in the platelet glycoprotein Ib alpha gene associated with a hyperactive surface receptor. Blood 1993, 81: |787-179|.

23. Matsubara $Y$, Murata M, Sugita K, Ikeda $Y$ : Identification of a novel point mutation in platelet glycoprotein Ibalpha, Gly to Ser at residue $\mathbf{2 3 3}$, in a Japanese family with platelet-type von Willebrand disease. J Thromb Haemost 2003, I:2198-2205.

24. Othman M, Notley C, Lavender FL, White H, Byrne CD, Lillicrap D, O'Shaughnessy DF: Identification and functional characterization of a novel 27-bp deletion in the macroglycopeptide-coding region of the GPIBA gene resulting in platelet-type von Willebrand disease. Blood 2005, 105:4330-4336.

25. Baglia FA, Badellino KO, Li CQ, Lopez JA, Walsh PN: Factor XI binding to the platelet glycoprotein Ib-IX-V complex pro- 
motes factor XI activation by thrombin. J Biol Chem 2002, 18:1662-1668

26. Beguin S, Kumar R, Keularts I, Seligsohn U, Coller BS, Hemker HC: Fibrin-dependent platelet procoagulant activity requires GPIb receptors and von Willebrand factor. Blood 1999, 93:564-570.

27. Al Dieri R, Bellucci S, Beguin S, Hemker HC, Caen J: Defective vWF-Fibrin-GPIb interaction causes impaired prothrombin consumption in Bernard-Soulier Syndrome [abstract]. J Thromb Haemost 2003:754.

28. Balduini CL, Cattaneo M, Fabris F, Gresele P, lolascon A, Pulcinelli FM, Savoia A: Inherited thrombocytopenias: a proposed diagnostic algorithm from the Italian Gruppo di Studio delle Piastrine. Haematologica 2003, 88:582-592.

29. Locatelli F, Rossi G, Balduini C: Hematopoietic stem-cell transplantation for the Bernard-Soulier syndrome. Ann Intern Med 2003, I38:79.

30. Kunishima S, Imai T, Hamaguchi M, Saito H: Novel heterozygous missense mutation in the second leucine rich repeat of GPIba affects GPIb/IX/V expression and results in macrothrombocytopenia in a patient initially misdiagnosed with idiopathic thrombocytopenic purpura. Eur J Haematol 2006, 76:348-355.

3I. Miller JL, Lyle VA, Cunningham D: Mutation of leucine-57 to phenylalanine in a platelet glycoprotein Ib alpha leucine tandem repeat occurring in patients with an autosomal dominant variant of Bernard-Soulier disease. Blood 1992, 79:439-446.

32. Kenny D, Jonsson OG, Morateck PA, Montgomery RR: Naturally occurring mutations in glycoprotein lb that result in defective ligand binding and synthesis of a truncated protein. Blood 1998, 92:175-183.

33. Li C, Martin SE, Roth G]: The genetic defect in two well-studied cases of Bernard-Soulier syndrome: a point mutation in the fifth leucine-rich repeat of platelet glycoprotein Ib alpha. Blood 1995, 86:3805-38|4.

34. Antonucci JV, Martin ES, Hulick PJ, Joseph A, Martin SE: BernardSoulier syndrome: Common ancestry in two African American families with the GP Ib Leu I 29Pro mutation. Am J Hematol 2000, 65: $14 \mid-148$.

35. Koskela S, Partanen J, Salmi TT, Kekomaki R: Molecular characterization of two mutations in platelet glycoprotein (GP) Ib alpha in two Finnish Bernard-Soulier syndrome families. Eur J Haematol 1999, 62:160-168.

36. Ware J, Russell SR, Marchese P, Murata M, Mazzucato M, De Marco $L$, Ruggeri ZM: Point mutation in a leucine-rich repeat of platelet glycoprotein Ib alpha resulting in the Bernard-Soulier syndrome. J Clin Invest 1993, 92:1213-1220.

37. Margaglione M, D'Andrea G, Grandone E, Brancaccio V, Amoriello A, Di Minno G: Compound heterozygosity (554-589 del, C5 I 5-T transition) in the platelet glycoprotein Ib alpha gene in a patient with a severe bleeding tendency. Thromb Haemost 1999, $81: 486-492$.

38. de la Salle C, Baas MJ, Lanza F, Schwartz A, Hanau D, Chevalier J, Gachet C, Briquel ME, Cazenave JP: A three-base deletion removing a leucine residue in a leucine-rich repeat of platelet glycoprotein Ib alpha associated with a variant of Bernard-Soulier syndrome (Nancy I). Br J Haematol 1995, 89:386-396.

39. Ulsemer P, Lanza F, Baas MJ, Schwartz A, Ravanat C, Briquel ME, Cranmer S, Jackson S, Cazenave JP, de la Salle C: Role of the leucine-rich domain of platelet GPIbalpha in correct post-translational processing - the Nancy I Bernard-Soulier mutation expressed on CHO cells. Thromb Haemost 2000, 84: I04-III.

40. Simsek S, Noris P, Lozano M, Pico M, von dem Borne AE, Ribera A, Gallardo D: Cys209 Ser mutation in the platelet membrane glycoprotein Ib alpha gene is associated with Bernard-Soulier syndrome. $\mathrm{Br}$ j Haematol I994, 88:839-844.

4I. Gonzalez-Manchon C, Larrucea S, Pastor AL, Butta N, Arias-Salgado EG, Ayuso MS, Parrilla R: Compound heterozygosity of the GPIbalpha gene associated with Bernard-Soulier syndrome. Thromb Haemost 2001, 86: I385-I39|

42. Ware J, Russell SR, Vicente V, Scharf RE, Tomer A, McMillan R, Ruggeri ZM: Nonsense mutation in the glycoprotein Ib alpha coding sequence associated with Bernard-Soulier syndrome. Proc Natl Acad Sci USA 1990, 87:2026-2030.
43. Kunishima S, Miura H, Fukutani $\mathrm{H}$, Yoshida $\mathrm{H}$, Osumi K, Kobayashi $\mathrm{S}$, Ohno R, Naoe T: Bernard-Soulier syndrome Kagoshima: Ser 444-->stop mutation of glycoprotein (GP) lb alpha resulting in circulating truncated GPIb alpha and surface expression of GPIb beta and GPIX. Blood 1994, 84:3356-3362

44. Holmberg L, Karpman D, Nilsson I, Olofsson T: Bernard-Soulier syndrome Karlstad: Trp 498-->Stop mutation resulting in a truncated glycoprotein lb alpha that contains part of the transmembranous domain. Br J Haematol 1997, 98:57-63.

45. Li C, Pasquale DN, Roth G): Bernard-Soulier syndrome with severe bleeding: absent platelet glycoprotein Ib alpha due to a homozygous one-base deletion. Thromb Haemost 1996 , 76:670-674.

46. Afshar-Kharghan V, Craig FE, Lopez JA: Bernard-Soulier syndrome in a patient doubly heterozygous for two frameshift mutations in the glycoprotein ib alpha gene. $\mathrm{Br} J$ Haematol 2000, I I 0:919-924

47. Simsek S, Noris P, Lozano M, Pico M, von dem Borne AE, Ribera A Gallardo D: Cys209 Ser mutation in the platelet membrane glycoprotein Ib alpha gene is associated with Bernard-Soulier syndrome. Br J Haematol 1994, 88:839-844.

48. Kanaji T, Okamura T, Kurolwa M, Noda M, Fujimura K, Kuramoto A, Sano M, Nakano S, Niho Y: Molecular and genetic analysis of two patients with Bernard-Soulier syndrome - identification of new mutations in glycoprotein Ib alpha gene. Thromb Haemost 1997, 77:|055-|06|.

49. Noda M, Fujimura $K$, Takafuta $T$, Shimomura $T$, Fujimoto $T$, Yamamoto N, Tanoue K, Arai M, Suehiro A, Kakishita E, Shimasaki A, Kuramoto A: Heterogeneous expression of glycoprotein Ib, IX and $V$ in platelets from two patients with Bernard-Soulier syndrome caused by different genetic abnormalities. Thromb Haemost 1995, 74:|4||-|4|5.

50. Noda M, Fujimura K, Takafuta T, Shimomura T, Fujii T, Katsutani S, Fujimoto T, Kuramoto A, Yamazaki T, Mochizuki T, Matsuzaki M, Sano M: A point mutation in glycoprotein IX coding sequence (Cys73 (TGT) to Tyr(TAT)) causes impaired surface expression of GPIb/IX/V complex in two families with BernardSoulier syndrome. Thromb Haemost 1996, 76:874-878.

5I. Mitsui T, Yokoyama S, Yazaki N, Hayashi T, Suzuki K, Shimizu Y, Kawakami T, Kanazawa C, Katsuura M, Ikegami T, Hayasaka K: Severe bleeding tendency in a patient with Bernard-Soulier syndrome associated with a homozygous single base pair deletion in the gene coding for the human platelet glycoprotein Ibalpha. J Pediatr Hematol Oncol 1998, 20:246-25I.

52. Afshar-Kharghan V, Lopez JA: Bernard-Soulier syndrome caused by a dinucleotide deletion and reading frameshift in the region encoding the glycoprotein Ib alpha transmembrane domain. Blood 1997, 90:2634-2643.

53. Kenny D, Newman PJ, Morateck PA, Montgomery RR: A dinucleotide deletion results in defective membrane anchoring and circulating soluble glycoprotein Ib alpha in a novel form of Bernard-Soulier syndrome. Blood 1997, 90:2626-2633.

54. Gonzalez-Manchon C, Butta N, Iruin G, Alonso S, Ayuso MS, Parrilla R: Disruption of the Cys5-Cys7 disulfide bridge in the platelet glycoprotein Ibbeta prevents the normal maturation and surface exposure of GPIb-IX complexes. Thromb Haemost 2003, 90:456-464.

55. Kunishima S, Naoe T, Kamiya T, Saito H: Novel heterozygous missense mutation in the platelet glycoprotein lb beta gene associated with isolated giant platelet disorder. Am J Hematol 200I, 68:249-255.

56. Hillmann A, Nurden A, Nurden P, Combrie R, Claeyssens S, Moran $N$, Kenny D: A novel hemizygous Bernard-Soulier Syndrome (BSS) mutation in the amino terminal domain of glycoprotein (GP) Ibbeta - platelet characterization and transfection studies. Thromb Haemost 2002, 88:1026-1032.

57. Strassel C, Pasquet JM, Alessi MC, Juhan-Vague I, Chambost H, Combrie R, Nurden P, Bas MJ, De La Salle C, Cazenave JP, Lanza F, Nurden AT: A novel missense mutation shows that GPIbbeta has a dual role in controlling the processing and stability of the platelet GPIb-IX adhesion receptor. Biochemistry 2003, 42:4452-4462.

58. Kunishima S, Tomiyama $Y$, Honda S, Fukunishi M, Hara J, Inoue $C$ Kamiya T, Saito H: Homozygous Pro74-->Arg mutation in the platelet glycoprotein Ibbeta gene associated with BernardSoulier syndrome. Thromb Haemost 2000, 84: I I2-I I7. 
59. Kurokawa Y, Ishida F, Kamijo T, Kunishima S, Kenny D, Kitano K, Koike K: A missense mutation (Tyr88 to Cys) in the platelet membrane glycoprotein Ibbeta gene affects GPIb/IX complex expression - Bernard-Soulier syndrome in the homozygous form and giant platelets in the heterozygous form. Thromb Haemost 200I, 86: I 249-1256.

60. Kunishima S, Lopez JA, Kobayashi S, Imai N, Kamiya T, Saito H, Naoe $\mathrm{T}$ : Missense mutations of the glycoprotein (GP) Ib beta gene impairing the GPIb alpha/beta disulfide linkage in a family with giant platelet disorder. Blood 1997, 89:2404-24I2.

61. Tang J, Stern-Nezer S, Liu PC, Matyakhina L, Riordan M, Luban NL, Steinbach PJ, Kaler SG: Mutation in the leucine-rich repeat Cflanking region of platelet glycoprotein Ib beta impairs assembly of von Willebrand factor receptor. Thromb Haemost 2004, 92:75-88.

62. Kunishima S, Yamazaki T, Matsushita T, Sako M, Hamaguchi M, Saito $\mathrm{H}$ : Variant Bernard-Soulier syndrome caused by compound heterozygous mutations in the GPIb beta gene [abstract]. Platelets 2004, I 5:374-375

63. de la Salle C, Lanza F, Caen J, Nurden P, Nurden AT, Juhan I, Briquel ME, Ternisien C, Conard J, Cazenave JP: Molecular characterization of five different mutations in patients with BernardSoulier bleeding disorder. Central role of platelet GPIbb and GPIX in GPIb-IX-V expression [abstract]. Thromb Haemost 1997:68.

64. Moran N, Morateck PA, Deering A, Ryan M, Montgomery RR, Fitzgerald DJ, Kenny D: Surface expression of GPIb alpha is dependent on GPIb beta: evidence from a novel mutation causing Bernard-Soulier syndrome. Blood 2000, 96:532-539.

65. Kunishima S, Matsushita T, Ito T, Kamiya T, Saito H: Novel nonsense mutation in the platelet glycoprotein lbbeta gene associated with Bernard-Soulier syndrome. Am J Hematol 2002, 7 I:279-284

66. Kenny D, Morateck PA, Gill JC, Montgomery RR: The critical interaction of glycoprotein (GP) IBbeta with GPIX-a genetic cause of Bernard-Soulier syndrome. Blood 1999, 93:2968-2975.

67. Watanabe R, Ishibashi T, Saitoh $Y$, Shichishima T, Maruyama $Y$, Enomoto Y, Handa M, Oda A, Ambo H, Murata M, Ikeda Y: Bernardsoulier syndrome with a homozygous 13 base pair deletion in the signal peptide-coding region of the platelet glycoprotein Ib(beta) gene. Blood Coagul Fibrinolysis 2003, I 4:387-394.

68. Strassel C, Alessi MC, Juhan-Vague I, Cazenave JP, Lanza F: A I 3 base pair deletion in the GPIbbeta gene in a second unrelated Bernard-Soulier family due to slipped mispairing between direct repeats. J Thromb Haemost 2004, 2: I663-I665.

69. Strassel C, David T, Eckly A, Baas MJ, Moog S, Ravanat C, Trzeciak MC, Vinciguerra C, Cazenave JP, Gachet C, Lanza F: Synthesis of GPIb beta with novel transmembrane and cytoplasmic sequences in a Bernard-Soulier patient resulting in GPIbdefective signaling in CHO cells. J Thromb Haemost 2006, 4:217-228.

70. Ludlow LB, Schick BP, Budarf ML, Driscoll DA, Zackai EH, Cohen A, Konkle BA: Identification of a mutation in a GATA binding site of the platelet glycoprotein lbbeta promoter resulting in the Bernard-Soulier syndrome. J Biol Chem 1996, 27 I:22076-22080.

7I. Lanza F, de la Salle C, Baas MJ, Schwartz A, Boval B, Cazenave JP, Caen JP: A Leu7Pro mutation in the signal peptide of platelet glycoprotein (GP)IX in a case of Bernard-Soulier syndrome abolishes surface expression of the GPIb-V-IX complex. $\mathrm{Br} J$ Haematol 2002, I I 8:260-266.

72. Rivera CE, Villagra J, Riordan M, Williams S, Lindstrom KJ, Rick ME: Identification of a new mutation in platelet glycoprotein IX (GPIX) in a patient with Bernard-Soulier syndrome. $\mathrm{Br} / \mathrm{Hae}$ matol 2001, I I 2: 105-108.

73. Wright SD, Michaelides K, Johnson DJ, West NC, Tuddenham EG: Double heterozygosity for mutations in the platelet glycoprotein IX gene in three siblings with Bernard-Soulier syndrome. Blood 1993, 81:2339-2347.

74. Noris P, Arbustini E, Spedini P, Belletti S, Balduini CL: A new variant of Bernard-Soulier syndrome characterized by dysfunctional glycoprotein (GP) Ib and severely reduced amounts of GPIX and GPV. Br J Haematol 1998, 103:1004-1013.

75. Clemetson JM, Kyrle PA, Brenner B, Clemetson KJ: Variant Bernard-Soulier syndrome associated with a homozygous muta- tion in the leucine-rich domain of glycoprotein IX. Blood 1994, 84: ||24-||3|.

76. Donner M, Karpman D, Kristoffersson AC, Winqvist I, Holmberg L: Recurrent mutation Asn45-->Ser of glycoprotein IX in Bernard-Soulier syndrome. Eur J Haematol 1996, 57: I 78-I79.

77. Koskela S, Javela K, Jouppila J, Juvonen E, Nyblom O, Partanen J, Kekomaki R: Variant Bernard-Soulier syndrome due to homozygous Asn45Ser mutation in the platelet glycoprotein (GP) IX in seven patients of five unrelated Finnish families. Eur J Haematol 1999, 62:256-264.

78. Vanhoorelbeke K, Schlammadinger A, Delville JP, Handsaeme J, Vandecasteele G, Vauterin S, Pradier O, Wijns W, Deckmyn H: Occurrence of the Asn45Ser mutation in the GPIX gene in a Belgian patient with Bernard Soulier syndrome. Platelets 200I, I 2:1 I4-120.

79. Sachs UJ, Kroll H, Matzdorff AC, Berghofer H, Lopez JA, Santoso S: Bernard-Soulier syndrome due to the homozygous Asn45Ser mutation in GPIX: an unexpected, frequent finding in Germany. Br J Haematol 2003, I23:|27-|3|.

80. Drouin J, Carson NL, Laneuville O: Compound heterozygosity for a novel nine-nucleotide deletion and the Asn45Ser missense mutation in the glycoprotein IX gene in a patient with Bernard-Soulier syndrome. Am J Hematol 2005, 78:4I-48.

8I. Suzuki K, Hayashi T, Yahagi A, Akiba J, Tajima K, Satoh S, Sasaki H: Novel point mutation in the leucine-rich motif of the platelet glycoprotein IX associated with Bernard-Soulier syndrome. BrJ Haematol 1997, 99:794-800.

82. Suzuki K, Hayashi T, Akiba J, Satoh S, Kato T: Phenotypic consequence of the gene abnormality in the platelet glycoprotein IX gene observed in a patient with Bernard-Soulier syndrome through mammalian cell expression system. Thromb Res 1999, 95:295-302.

83. Kunishima S, Tomiyama Y, Honda S, Kurata Y, Kamiya T, Ozawa K, Saito H: Cys97-->Tyr mutation in the glycoprotein IX gene associated with Bernard-Soulier syndrome. $\mathrm{Br} J$ Haematol 1999, I 07:539-545.

84. Wang Z, Zhao X, Duan W, Fu J, Lu M, Wang G, Bai X, Ruan C: A novel mutation in the transmembrane region of glycoprotein IX associated with Bernard-Soulier syndrome. Thromb Haemost 2004, 92:606-6I3.

85. Garner C, Best S, Menzel S, Rooks H, Spector TD, Thein SL: Two candidate genes for low platelet count identified in an Asian Indian kindred by genome-wide linkage analysis: glycoprotein IX and thrombopoietin. Eur J Hum Genet 2006, I 4: I0I-I08.

86. Iwanaga $M$, Kunishima S, Ikeda S, Tomonaga M, Naoe T: Vulnerable mutation Trp I 26-->stop of glycoprotein IX in Japanese Bernard-Soulier syndrome. Eur J Haematol 1998, 60:264-246.

Publish with BioMed Central and every scientist can read your work free of charge

"BioMed Central will be the most significant development for disseminating the results of biomedical research in our lifetime. "

Sir Paul Nurse, Cancer Research UK

Your research papers will be:

- available free of charge to the entire biomedical community

- peer reviewed and published immediately upon acceptance

- cited in PubMed and archived on PubMed Central

- yours - you keep the copyright 